\title{
Variasi Perbandingan Terigu Dan Tepung Millet (Panicum milliaceum) Terhadap Karakteristik Donat
}

\author{
Variation of Wheat and Millet (Panicum milliaceum) Flour on the \\ Characteristics of Donut
}

\author{
Yuliana $^{1}$, I Desak Putu Kartika Pratiwi ${ }^{1 *}$, NM Indri Hapsari Arihantana1 \\ Program Studi Teknologi Pangan, Fakultas Teknologi Pertanian, Universitas Udayana \\ Kampus Bukit Jimbaran, Badung-Bali \\ *Penulis korespondensi: ID.P.Kartika Pratiwi, Email: kartika.pratiwi@unud.ac.id
}

\begin{abstract}
Donuts are flour based foods. The weakness of donuts is that the basic ingredients used are still imported, so there is an increase in the use of alternative flour, namely millet flour. The research aims to find out the ratio effect of wheat and millet flour to the characteristic of donut, and to determine the precise ratio between wheat and millet flour which can produce donuts with the best characteristic. This research used a Completely Randomized Design with a treatmen of ratio between wheat flour and millet flour which consist by 6 levels: 100\%:0\%, 90\%:10\%, 80\%:20\%, 70\%:30\%, 60\%:40\%, and 50\%:50\%. The treatment was repeated 3 times to obtain 18 experimental units. The data obtained were analyzed by variance and if treatment had a significant effect then followed by duncan test. The result of research showed that the ratio of $80 \%$ wheat and $20 \%$ millet flour resulted in the best characteristic of donut with expand power of $116,69 \%$, colour quantity L 52,77, a* 9,51, b*34,37, water content of $25.88 \%$ (wb), protein content of $8.17 \%(\mathrm{wb})$, crude fiber content of $5,06 \%(\mathrm{wb})$, tannin content of $0,15 \%(\mathrm{wb})$, colour golden yellow, flavor rather liked, texture rather liked and soft, appearance of rather large pores, taste rather liked and overall acceptance rather liked.
\end{abstract}

Keywords : wheat, millet flour, characteristic of donut

\section{PENDAHULUAN}

Donat merupakan salah satu makanan selingan atau kudapan yang cukup populer di Indonesia. Donat (doughnuts atau donut) adalah jenis roti yang proses memasaknya dengan cara digoreng dan memiliki bentuk khas dengan lubang di tengah seperti cincin atau berbentuk bola jika diisi sesuatu (Subagjo, 2007). Donat merupakan olahan pangan yang berbahan dasar terigu, kelemahan dari donat yaitu bahan dasar yang digunakan masih diimpor. Listriyani (2016) melaporkan bahwa kebutuhan terigu di
Indonesia terus meningkat yaitu 6,25 juta ton (2011-2012); 6,95 juta ton (2012-2013); 7,16 juta ton (2013-2014); 7,36 juta ton (2014-2015) dan mencapai 7,95 juta ton (2015-2016). Pengurangan ketergantungan terhadap terigu sebagai bahan dasar donat dapat dilakukan melalui peningkatan penggunaan tepung alternatif lainnya, salah satunya adalah tepung millet. Proso millet (Pannicum milliaceum) adalah salah satu jenis millet yang dibudidayakan di Indonesia, pemanfaatan proso millet cukup rendah bagi konsumsi pangan, padahal 
proso millet memiliki nilai kandungan gizi yang mirip dengan tanaman pangan lainnya seperti padi, jagung, gandum, dan tanaman biji-bijian yang lain (Hartono, 2010). Menurut National Nutrient Database (2012) proso millet mengandung protein $11,02 \%$, lemak $4,22 \%$, air $8,67 \%$, abu $3,25 \%$, dan karbohidrat 72,85\%. Peningkatan peranan proso millet di bidang pangan dilakukan dengan pengolahan menjadi tepung millet melalui metode kecambah fermentasi. Metode tersebut dapat menurunkan kadar tanin tepung millet secara signifikan dari $2,92 \%$ menjadi $0,59 \%$ (Mahendra et al, 2019). Penurunan kadar tanin bertujuan mengurangi rasa pahit yang dapat mempengaruhi rasa dari produk. Selain itu, metode kecambah fermentasi menghasilkan tepung dengan kadar air sebesar 12,36\%, kadar abu sebesar 1,45\%, kadar karbohidrat sebesar $81,80 \%$, kapasitas penyerapan air sebesar $172,85 \%$, kapasitas penyerapan minyak sebesar $107,73 \%$, swelling power sebesar 10,11 g/g, dan indeks kelarutan dalam air sebesar $44,1 \%$ (Mahendra et al., 2019). Proso millet yang diolah menjadi tepung dengan metode kecambah fermentasi disebut tepung millet. Kelebihan lainnya dari tepung millet adalah kandungan serat pangan sebesar 12,55\% (bk) (Pratiwi dan Sugitha, 2020). Beberapa penelitian telah melaporkan pemanfaatan tepung millet dalam pengolahan produk pangan seperti flakes, biskuit Mpasi, dan snack bar (Dewi et al.,(2018); Pratiwi dan
Hapsari (2019); Pratiwi dan Sugitha (2020). Pemanfaatan tepung millet dalam pengolahan donat belum pernah dilaporkan. Pengolahan donat dengan perbandingan tepung lain telah diteliti sebelumnya oleh Tamba et al., (2014) yang melaporkan bahwa perbandingan $30 \%$ tepung labu kuning dengan $70 \%$ terigu menghasilkan donat dengan mutu yang terbaik. Selanjutnya Anggarini dan Dwi (2015) melaporkan bahwa donat dengan substitusi bekatul 20\% dan 40\% lebih empuk, lebih putih, dan lebih disukai. Donat karakteristik terbaik adalah donat dengan substitusi bekatul $20 \%$ dan $40 \%$, dengan kandungan serat masing-masing $1,28 \%$ dan $2,36 \%$. Tepung bahan lain belum mampu sepenuhnya berperan menggantikan terigu karena tidak mengandung gluten, sehingga tepung dari bahan pangan lokal baru bisa mensubstitusi terigu sekitar 25-30\%, terutama untuk aneka roti dan mi (Ratnaningsih et al., 2010 dalam Faridah dan Widjanarko, 2014).

Tepung non terigu tidak dapat menggantikan terigu $100 \%$ dalam pengolahan donat, hal ini dikarenakan tepung non terigu, salah satunya adalah tepung millet, tidak mengandung gluten. Gluten merupakan protein heterogen yang terdiri dari protein gliadin dan glutein yang dikandung terigu (Wrigley et al., 2006), gluten diperlukan dalam proses pengembangan adonan donat. Selain itu, tepung millet masih mengandung tanin 
sebanyak $0,59 \%$ sehingga apabila digunakan sampai $100 \%$ dalam pembuatan donat, dapat mempengaruhi rasa dari donat akibat timbulnya aftertaste pahit. Oleh karena itu, dalam pembuatan donat harus diperhitungkan variasi perbandingan terigu dengan tepung millet yang tepat, sehingga dapat menghasilkan donat dengan kualitas sensoris yang dapat diterima oleh panelis. Berdasarkan hal tersebut, untuk meningkatkan pemanfaatan tepung millet dalam pengolahan donat, maka perlu dilakukan penelitian mengenai variasi perbandingan terigu dengan tepung millet sehingga dapat menghasilkan donat dengan karakteristik terbaik.

\section{METODE PENELITIAN}

\section{Tempat dan waktu penelitian}

Penelitian ini dilaksanakan di Laboratorium Pengolahan Pangan dan Laboratorium Analisis Pangan, Fakultas Teknologi Pertanian, Universitas Udayana. Pelaksanaan penelitian ini dilakukan pada bulan Desember 2019 sampai dengan Mei 2020.

\section{Bahan dan Alat}

Bahan utama yang digunakan dalam pembuatan donat millet adalah proso millet yang diperoleh dari pasar burung sanglah, Denpasar, terigu (cakra kembar) yang diperoleh dari Toko Kurnia, Jimbaran. Bahan tambahan yang digunakan yaitu telur, gula pasir (gulaku), garam (dolphin), susu bubuk (dancow), ragi instan (fermipan), margarin (forvita), dan air mineral (aqua) yang diperoleh dari Toko Kurnia, Jimbaran. Bahan kimia yang digunakan dalam melakukan analisis meliputi $\mathrm{H}_{2} \mathrm{SO} 4$ (Merck), $\mathrm{NaOH}$ PA (Merck), $\mathrm{HCl}$ (Merck), heksan (Merck), alkohol 96\% (Merck), Tablet kjeldahl (Merck), asam borat, $\mathrm{NaOH}$ teknis (Merck), aquades, folin denis (Merck), asam tanat (Sigma), Na2CO3 (Sigma) dan indikator PP. Alat-alat yang digunakan dalam melaksanakan penelitian ini antara lain waskom, timbangan analitik (Shimadzu), ayakan 60 mesh (Retsch), blender (Cosmos), mixer (Miyako), timbangan digital (EKS), kuas untuk ayakan, gelas ukur (Pyrex), kompor gas (Rinnai), sutil, sendok, gunting. Alat yang digunakan untuk analisis sifat fisik dan kimia adalah lumpang, kertas saring, kertas whatman 42 , corong, eksikator, botol timbang, oven (Memmert), timbangan analitik (Shimadzu), aluminium foil, pinset, pipet tetes, pipet volume (Pyrex), kompor listrik, labu kjeldahl (Pyrex), destruktor, labu erlenmeyer (Pyrex), gelas beaker (Pyrex), gelas ukur (Pyrex), destilator, biuret (Pyrex), pompa karet, labu takar (Pyrex), tabung reaksi (Pyrex), water bath (thermology), colorymeter, kamera Hp (Oppo), perangkat komputer dan lembar quisioner. Selain itu untuk evaluasi sensoris produk, alat yang digunakan adalah piring kertas.

\section{Rancangan Percobaan}

Penelitian dilakukan dengan menggunakan Rancangan Acak Lengkap (RAL) dengan perlakuan perbandingan 
terigu dan tepung millet terdiri dari 6 taraf, yaitu: $\mathrm{P} 1=100 \%: 0 \%, \mathrm{P} 2=90 \%: 10 \%, \mathrm{P} 3$ $=80 \%: 20 \%, \mathrm{P} 4=70 \%: 30 \%, \mathrm{P} 5=60 \%$ : $40 \%, \mathrm{P} 6=50 \%: 50 \%$. Masing-masing perlakuan diulang sebanyak 3 kali sehingga diperoleh 18 unit percobaan. Data yang diperoleh akan dianalisis menggunakan sidik ragam dan apabila terdapat pengaruh dilanjutkan dengan uji Duncan Multiple Range Test.

\section{Pelaksanaan Penelitian}

Pelaksanaan penelitian terdiri dari 2 tahap yaitu: pembuatan tepung millet dan pembuatan donat

\section{Pembuatan Tepung Millet}

Proses pembuatan tepung millet: biji proso millet berwarna kuning ditimbang sebanyak $500 \mathrm{~g}$ dan dicuci dengan air hingga bersih, kemudian direndam selama 12 jam. Setelah 12 jam, biji millet ditiriskan, diletakkan pada wadah yang ditutupi kain basah, dan dikecambahkan selama 72 jam. Selama proses perkecambahan, biji millet disiram dengan air $50 \mathrm{ml}$ secara merata setiap 12 jam. Biji millet yang telah berkecambah kemudian dicuci dan diletakkan pada wadah steril (toples kaca) dan direndam aquadest steril dengan ratio 1:2 (w/v) dalam keadaan tertutup. Fermentasi spontan secara sub merge dilakukan selama 24 jam. Setelah difermentasi, millet dicuci dengan air mengalir, ditiriskan dan dikeringkan menggunakan oven, suhu $50^{\circ} \mathrm{C}$ selama 3 jam, kemudian dihaluskan menggunakan blender dan diayak menggunakan ayakan 60 mesh.

\section{Pembuatan Donat}

Pembuatan donat dimulai dengan pencampuran terigu dengan tepung millet sesuai perlakuan, kemudian gula pasir, susu bubuk, ragi instan, kuning telur dan air ditimbang sesuai formulasi yang terdapat pada Tabel 1, lalu diaduk hingga rata sambil dituangi air $50 \mathrm{ml}$ sedikit demi sedikit. Garam dan margarin ditambahkan sesuai formulasi dan diuleni hingga kalis. Adonan kemudian difermentasi selama 30 menit, selanjutnya adonan ditimbang dengan berat $38 \mathrm{~g}$ untuk setiap perlakuan. Adonan dibentuk seperti bola, lalu dilubangi bagian tengahnya menggunakan cetakan donat dan difermentasi kembali selama 60 menit. Sebelum menggoreng, adonan minyak dipanaskan terlebih dahulu selama 3 menit. Selanjutnya, adonan yang sudah mengembang digoreng sampai matang (berwarna kecoklatan) selama 5 menit. Setelah itu, donat diangkat dan didinginkan (Suprapto et al., (2012) dalam Swandani et al., (2017) yang dimodifikasi)

\section{Variabel yang Diamati}

Variabel yang diamati pada penelitian ini meliputi daya kembang ditentukan menggunakan metode Seed Displancement Test (Bakrie, 1990)., kuantitas warna ditentukan menggunakan metode colorimeter (Belinda dan Yunianta, 2016), kadar air dengan menggunakan metode pengeringan (Sudarmadji et al., 
1997), kadar protein dengan menggunakan metode Mikro-Kjeldhal (Sudarmadji et al., 1997), kadar serat kasar dengan metode hidrolisis asam basa (Sudarmadji et.al,1997), kadar tannin dengan metode spektrofotometer (AOAC, 2006) dan evaluasi sensoris terhadap warna, aroma, tekstur, kenampakan pori-pori, rasa dan penerimaan keseluruhan (Soekarto, 1985).

\section{HASIL DAN PEMBAHASAN}

Nilai rata-rata daya kembang donat terdapat pada Tabel 1. Nilai rata-rata kuantitas warna donat terdapat pada Tabel 2. Nilai rata-rata kadar air, kadar protein, kadar serat kasar dan kadar tanin pada donat terdapat pada Tabel 3.

\section{Daya Kembang}

Hasil sidik ragam menunjukkan bahwa perbandingan terigu dan tepung millet berpengaruh nyata $(\mathrm{P}<0,05)$ terhadap daya kembang donat yang dihasilkan. Tabel 1 menunjukkan daya kembang donat berkisar antara $72,95 \%$ - 202,17\%. Daya kembang tertinggi dihasilkan pada perlakuan $\mathrm{P} 1$ sebesar 202,17\% sedangkan daya kembang terendah dihasilkan pada perlakuan P6 sebesar 72,95\% dan tidak berbeda nyata dengan perlakuan P4 dan P5.

Semakin tinggi penggunaan tepung millet sebagai bahan pengganti terigu, maka daya kembang donat semakin menurun. Penurunan daya kembang donat disebabkan karena menurunnya kandungan gluten pada adonan tepung akibat meningkatnya penggunaan tepung millet. Menurut Purnomo (1994) dalam Sarofa et al (2014), adonan yang ditambahkan terigu protein tinggi memiliki volume yang lebih tinggi karena mempunyai kapasitas merangkap gas $\mathrm{CO} 2$ lebih tinggi. Selama proses fermentasi terjadi pengembangan volume adonan, hal ini disebabkan karena selama proses fermentasi berlangsung akan terbentuk gas $\mathrm{CO} 2$, gas $\mathrm{CO} 2$ ini akan ditahan oleh gluten sehingga terjadi pengembangan volume yang akan membuat adonan menjadi ringan dan lebih besar (Fardiaz, 1992 dalam Devi, 2011). Tingkat pengembangan erat kaitannya dengan kemampuan adonan menahan gelembung-gelembung $\mathrm{CO}_{2}$ selama proses fermentasi (Wijayanti, 2007). Penurunan kemampuan adonan menahan gas yang terutama dipengaruhi kandungan gluten sehingga pengembangan yang makin tidak baik, akibatnya pori-pori tidak merata (Surono et al., 2017). Roti yang tidak mengembang memiliki pori pori yang cenderung kecil dan tidak seragam (Raharjo, 2019), sehingga semakin bertambahnya penggunaan tepung millet maka daya kembang donat yang dihasilkan semakin menurun dan pori-pori akan semakin kecil dan tidak merata.

Daya kembang juga dipengaruhi oleh jumlah air yang diikat oleh adonan. Proses penggorengan adonan mengalami kehilangan air. Hal ini menyebabkan lapisan gluten memerangkap dan memisahkan gas satu sama lain dengan membentuk lapisan 
pelindung menjadi buih kemudian menjadi tegar dan adonan mengembang (Potter, 1978). Tepung yang mengikat sedikit air akan menghasilkan adonan yang tidak elastis dan kaku sedangkan tepung yang memiliki daya ikat air yang baik akan menghasilkan adonan yang elastis dan mudah mengembang (Syahputri dan Wardani, 2014).

Tabel 1. Nilai rata-rata daya kembang donat

\begin{tabular}{cc}
\hline Perlakuan (Terigu : Tepung Millet) & Daya kembang (\%) \\
\hline P1 (100\%:0\%) & $202,17 \pm 12,87 \mathrm{a}$ \\
P2 (90\%:10\%) & $150 \pm 10,82 \mathrm{~b}$ \\
P3 (80\%:20\%) & $116,69 \pm 25,24 \mathrm{c}$ \\
P4 (70\%:30\%) & $83,34 \pm 3,63 \mathrm{~d}$ \\
P5 (60\%:40\%) & $77,09 \pm 9,57 \mathrm{~d}$ \\
P6 (50\%:50\%) & $72,95 \pm 25,96 \mathrm{~d}$ \\
\hline
\end{tabular}

Keterangan : Nilai rata - rata yang diikuti oleh huruf yang berbeda pada kolom yang sama menunjukkan berbeda nyata $(\mathrm{P}<0,05)$.

Tabel 2. Nilai rata-rata kuantitas warna donat

\begin{tabular}{cccc} 
Perlakuan & \multicolumn{3}{c}{ Warna $(\%)$} \\
\cline { 2 - 4 } (Terigu: Tepung Millet) & $\mathrm{L}$ & $\mathrm{a}^{*}$ & $\mathrm{~b}^{*}$ \\
\hline P1 (100\%:0\%) & $53,90 \pm 2,02 \mathrm{a}$ & $9,88 \pm 1,53 \mathrm{bc}$ & $34,38 \pm 2,23 \mathrm{a}$ \\
P2 (90\%:10\%) & $52,99 \pm 1,17 \mathrm{a}$ & $9,02 \pm 0,70 \mathrm{c}$ & $34,01 \pm 0,20 \mathrm{a}$ \\
P3 (80\%:20\%) & $52,77 \pm 0,95 \mathrm{a}$ & $9,51 \pm 0,79 \mathrm{c}$ & $34,37 \pm 1,32 \mathrm{a}$ \\
P4 (70\%:30\%) & $49,17 \pm 1,80 \mathrm{~b}$ & $10,34 \pm 0,27 \mathrm{bc}$ & $33,62 \pm 1,64 \mathrm{a}$ \\
P5 (60\%:40\%) & $46,08 \pm 1,17 \mathrm{c}$ & $12,08 \pm 1,17 \mathrm{a}$ & $33,57 \pm 0,97 \mathrm{a}$ \\
P6 (50\%:50\%) & $42,65 \pm 0,38 \mathrm{~d}$ & $11,56 \pm 0,44 \mathrm{ab}$ & $29,59 \pm 0,67 \mathrm{~b}$ \\
\hline
\end{tabular}

Keterangan : Nilai rata - rata yang diikuti oleh huruf yang berbeda pada kolom yang sama menunjukkan berbeda nyata $(\mathrm{P}<0,05)$.

\section{Kuantitas Warna}

Hasil sidik ragam menunjukkan bahwa perbandingan terigu dan tepung millet berpengaruh nyata $(\mathrm{P}<0,05)$ terhadap kuantitas warna donat yang dihasilkan. Tabel 2 menunjukkan nilai $\mathrm{L}$ donat berkisar antara antara 42,65 sampai dengan 53,90. Kecerahan warna donat tertinggi diperoleh pada perlakuan P1 dengan nilai L 53,90 namun tidak berbeda nyata $(\mathrm{P}<0,05)$ dengan P2 dan P3 sedangkan kecerahan warna donat terendah yaitu diperoleh perlakuan P6 dengan nilai L 42,65.
Tabel 2 menunjukkan bahwa donat cenderung mengalami peningkatan nilai a* seiring dengan meningkatnya penggunaan tepung millet. Nilai rata-rata $a^{*}$ dengan penambahan tepung millet antara 9,02 sampai dengan 12,08. Nilai $a^{*}$ tertinggi diperoleh dari perlakuan P5 namun tidak berbeda nyata $(\mathrm{P}<0,05)$ dengan perlakuan P6. Nilai $a^{*}$ terendah diperoleh dari perlakuan P2 namun tidak berbeda nyata $(\mathrm{P}<0,05)$ dengan perlakuan $\mathrm{P} 1, \mathrm{P} 3$, dan $\mathrm{P} 4$. Semakin besar nilai a* maka warna yang dihasilkan cenderung kemerah-merahan. 
Tabel 2 juga menunjukkan bahwa donat cenderung mengalami penurunan nilai b*seiring dengan meningkatnya penggunaan tepung millet. Nilai rata-rata $b^{*}$ dengan penambahan tepung millet antara 29,59 sampai dengan 34,83 . Nilai $b^{*}$ tertinggi diperoleh dari pelakuan P1 yaitu 34,83 dan tidak berbeda nyata dengan perlakuan $\mathrm{P} 2$, P3, P4, dan P5. Nilai b* terendah diperoleh dari perlakuan P6 yaitu 29,59. Semakin besar nilai $b^{*}$ maka warna yang dihasilkan cenderung kekuning-kuningan.

Pembentukan warna pada donat dipengaruhi oleh adanya reaksi antara karbohidrat, khususnya gula pereduksi dengan protein. Reaksi ini disebut reaksi Maillard. Hasil reaksi tersebut menghasilkan bahan berwarna coklat yang diinginkan dalam pembuatan roti (Winarno, 1992). Pada donat reaksi maillard terjadi pada bagian kulit yang menjadi berwarna coklat setelah penggorengan (baking). Warna remah (crumb) donat P6 lebih kusam atau gelap karena penambahan tepung millet sebesar $50 \%$ dan warna tepung millet cenderung kusam atau gelap.

Tabel 3. Nilai rata-rata kadar air, kadar protein, kadar serat kasar dan kadar tanin pada donat

\begin{tabular}{ccccc}
\hline $\begin{array}{c}\text { Perlakuan } \\
\text { (Terigu:Tepung } \\
\text { Millet) }\end{array}$ & Kadar Air (\%) & $\begin{array}{c}\text { Kadar } \\
\text { protein(\%) }\end{array}$ & $\begin{array}{c}\text { Kadar serat kasar } \\
(\%)\end{array}$ & $\begin{array}{c}\text { Kadar Tanin } \\
(\%)\end{array}$ \\
\hline P1 (100\%:0\%) & $26,95 \pm 0,92 \mathrm{a}$ & $9,22 \pm 0,44 \mathrm{a}$ & $3,10 \pm 3,37 \mathrm{e}$ & $0.10 \pm 0.02 \mathrm{~d}$ \\
P2 (90\%:10\%) & $26,87 \pm 0,63 \mathrm{a}$ & $8,54 \pm 0,23 \mathrm{~b}$ & $4,63 \pm 0,31 \mathrm{de}$ & $0.11 \pm 0.01 \mathrm{~cd}$ \\
P3 (80\%:20\%) & $25,88 \pm 0,98 \mathrm{ab}$ & $8,17 \pm 0,34 \mathrm{~b}$ & $5,06 \pm 1,57 \mathrm{~cd}$ & $0.15 \pm 0.028 \mathrm{c}$ \\
P4 (70\%:30\%) & $25,97 \pm 0,12 \mathrm{ab}$ & $8,02 \pm 0,23 \mathrm{bc}$ & $6,64 \pm 0,67 \mathrm{bc}$ & $0.20 \pm 0.031 \mathrm{~b}$ \\
P5 (60\%:40\%) & $24,73 \pm 0,89 \mathrm{bc}$ & $7,96 \pm 0,51 \mathrm{bc}$ & $8,39 \pm 0,95 \mathrm{~b}$ & $0.21 \pm 0.012 \mathrm{ab}$ \\
P6 (50\%:50\%) & $23,80 \pm 0,24 \mathrm{c}$ & $7,41 \pm 0,64 \mathrm{c}$ & $10,27 \pm 1,18 \mathrm{a}$ & $0.24 \pm 0.017 \mathrm{a}$ \\
\hline
\end{tabular}

Keterangan: Nilai rata - rata yang diikuti oleh huruf yang berbeda pada kolom yang sama menunjukkan berbeda nyata $(\mathrm{P}<0,05)$.

\section{Kadar Air}

Hasil sidik ragam menunjukkan bahwa perbandingan terigu dan tepung millet berpengaruh nyata $(\mathrm{P}<0,05)$ terhadap kadar air donat yang dihasilkan. Tabel 3 menunjukkan kadar air donat berkisar antara 23,80\% - 26,95\%. Kadar air tertinggi dihasilkan pada perlakuan P1 sebesar $26,95 \%$ dan tidak berbeda nyata dengan perlakuan P2, P3 dan P4. Kadar air terendah dihasilkan pada perlakuan P6 sebesar $23,80 \%$ dan tidak berbeda nyata dengan perlakuan P5.

$$
\text { Berdasarkan SNI 01-2000 }
$$
mengenai syarat mutu donat, kadar air donat maksimal 40\%, kadar air donat yang dihasilkan pada penelitian ini sudah memenuhi syarat SNI. Tabel 4, menunjukkan terjadi penurunan kadar air donat seiring dengan peningkatan 
penggunaan tepung millet. Semakin tinggi penambahan tepung millet maka kadar air donat yang dihasilkan cenderung semakin rendah. Hal tersebut diduga disebabkan karena perbedaan kadar air dari tepung yang digunakan. Kadar air tepung millet sebesar 12,36\% (Mahendra et al.,2019), sedangkan kadar air terigu sebesar 14,3\% (Anon., 2009).

Kadar air donat diduga juga dipengaruhi oleh kandungan protein dari kedua bahan baku. Terigu memiliki kadar protein lebih tinggi dibandingkan protein tepung millet dengan nilai protein berturutturut 12,57\% dan 11,02\% (Anon, 2009); (Abdel-Rahaman et al., 2005). Menurut Nugrahani (2005), pada tingkat penambahan air dalam jumlah yang sama, tepung yang memiliki kandungan protein tinggi mempunyai daya serap air lebih besar daripada tepung dengan kandungan protein rendah. Air berfungsi dalam pembentukan gluten dengan menghidrasi gliadin dan glutenin dalam tepung terigu (Matz, 1992).

Kadar air juga dipengaruhi oleh kapasitas pengikatan air atau daya ikat air (water holding capacity) dari tepung yang digunakan dalam pembuatan donat. tepung millet mengikat sedikit air dibandingkan terigu, sehingga adonan yang dihasilkan kurang elastis dan kaku. tepung millet mengandung pati yaitu amilosa dan amilopektin. Amilosa berpengaruh terhadap daya ikat air pada adonan, semakin banyak kadar amilosa yang digunakan maka akan menurunkan kadar air bahan pangan (Hartika, 2009). Semakin tinggi penggunaan tepung millet maka semakin kering dan rapuh donat yang dihasilkan. Hal tersebut sesuai dengan pernyataan Ahza (1983) yang menyatakan bahwa terigu memiliki pentosan dan gluten dalam jumlah tinggi, kedua komponen tersebut berpengaruh pada kapasitas pengikatan air yang tinggi pada terigu.

Kadar air juga dipengaruhi oleh kandungan serat dari kedua bahan. Terigu memiliki kadar serat yang lebih rendah dibandingkan tepung millet dengan nilai serat berturut-turut $2,5 \%$ dan $12,55 \%$ (bk) (Sunarsi et al., 2011); (Pratiwi dan Sugitha, 2020). Tepung yang memiliki kandungan serat yang tinggi tidak mampu menahan air untuk tetap dalam adonan, melainkan akan hilang selama proses pemasakan (Yunani, 2017 dalam Raharjo, 2019), sehingga semakin bertambahnya penggunaan tepung millet maka kadar air akan semakin berkurang.

\section{Kadar Protein}

Hasil sidik ragam menunjukkan bahwa perbandingan terigu dan tepung millet berpengaruh nyata $(\mathrm{P}<0,05)$ terhadap kadar protein donat yang dihasilkan. Tabel 3 menunjukkan kadar protein donat berkisar antara 7,41\% - 9,22\%. Kadar protein tertinggi dihasilkan pada perlakuan P1 sebesar 9,22\% sedangkan kadar protein terendah dihasilkan pada 
perlakuan P6 sebesar 7,41\% dan tidak berbeda nyata dengan perlakuan P4 dan P5. Kadar protein donat menurun seiring dengan peningkatan penggunaan tepung millet. Hal ini dikarenakan kandungan protein tepung millet lebih rendah dibandingkan dengan terigu. Kadar protein millet yaitu 11,02 \% (Abdel-Rahaman et al., 2005) dan kadar protein terigu yaitu 12,57\% (Anon,2009).

\section{Kadar Serat Kasar}

Hasil sidik ragam menunjukkan bahwa perbandingan terigu dan tepung millet berpengaruh nyata $(\mathrm{P}<0,05)$ terhadap kadar serat kasar donat yang dihasilkan. Tabel 3 menunjukkan kadar serat donat berkisar antara 3,10\% - 10,27\% . Kadar serat kasar tertinggi dihasilkan pada perlakuan P6 sebesar 10,27\%. Kadar serat kasar terendah dihasilkan pada perlakuan P1 sebesar $3,10 \%$ dan tidak berbeda nyata $(\mathrm{P}<0,05)$ dengan perlakuan P2. Tabel 4, menunjukkan terjadi peningkatan kadar serat donat seiring dengan peningkatan penggunaan tepung millet sebagai bahan pengganti terigu. Semakin tinggi tepung millet maka semakin tinggi kandungan serat kasar donat. Peningkatan kadar serat dari donat dipengaruhi oleh kadar serat dari kedua jenis tepung. Kadar serat terigu lebih rendah dibandingkan tepung millet. Kandungan serat pada terigu sebesar 2,5\% (Sunarsi et al., 2011), sedangkan kandungan serat pada tepung millet sebesar 12,55\% (bk) (Pratiwi dan Sugitha, 2020).

\section{Kadar Tanin}

Hasil sidik ragam menunjukkan bahwa perbandingan terigu dan tepung millet berpengaruh nyata $(\mathrm{P}<0,05)$ terhadap kadar tanin donat yang dihasilkan. Tabel 3 menunjukkan kadar tanin donat berkisar antara $0,10 \%-0,24 \%$. Kadar tanin tertinggi dihasilkan pada perlakuan P6 sebesar $0,24 \%$ dan tidak berbeda nyata $(\mathrm{P}<0,05)$ dengan perlakuan P5. Kadar tanin terendah dihasilkan pada perlakuan P1 sebesar $0,10 \%$ dan tidak berbeda nyata $(\mathrm{P}<0,05)$ dengan perlakuan $\mathrm{P} 2$.

Semakin tinggi penggunaan tepung millet maka semakin tinggi kadar tanin donat. Hal ini disebabkan karena tepung millet memiliki kadar tanin sebesar 0,59\% (Mahendra et al., 2019). Kandungan tanin pada donat dapat memberikan rasa sepat yang tidak diharapkan pada donat. Apabila konsentrasi tanin pada pangan rendah, tanin tersebut dapat berperan sebagai antioksidan pada tumbuhan, akan tetapi bila konsentrasi tanin tinggi dapat bernilai negatif pada tubuh (Katresna, 2017).

\section{Evaluasi Sensoris}

Evaluasi sensori donat dilakukan dengan uji hedonik dan skoring. Uji hedonik dilakukan terhadap warna, aroma, tekstur, rasa dan penerimaan keseluruhan. Uji skoring dilakukan terhadap warna, tekstur dan kenampakan pori-pori. Nilai 
rata-rata uji hedonik terhadap warna, aroma, tekstur, rasa dan penerimaan keseluruhan donat dapat dilihat pada Tabel
4. Nilai rata-rata uji skoring terhadap warna, tekstur dan kenampakan pori-pori dapat dilihat pada Tabel 5 .

Tabel 4. Nilai rata-rata uji hedonik warna, aroma, tekstur, rasa dan penerimaan keseluruhan donat

\begin{tabular}{cccccc}
\hline $\begin{array}{c}\text { Perlakuan } \\
\text { (Terigu:Tepung } \\
\text { Millet) }\end{array}$ & Warna & Aroma & Tekstur & Rasa & $\begin{array}{c}\text { Penerimaan } \\
\text { Keseluruhan }\end{array}$ \\
\hline P1 (100\%:0\%) & $4,78 \pm 0,51 \mathrm{a}$ & $4,21 \pm 0,90 \mathrm{a}$ & $4,04 \pm 1,10 \mathrm{ab}$ & $4,30 \pm 0,92 \mathrm{a}$ & $4,48 \pm 0,79 \mathrm{a}$ \\
P2 (90\%:10\%) & $4,65 \pm 0,64 \mathrm{ab}$ & $4,21 \pm 0,80 \mathrm{a}$ & $4,43 \pm 0,72 \mathrm{a}$ & $4,30 \pm 0,88 \mathrm{a}$ & $4,34 \pm 0,78 \mathrm{a}$ \\
P3 (80\%:20\%) & $4,17 \pm 0,78 \mathrm{~b}$ & $4,13 \pm 0,76 \mathrm{a}$ & $4,04 \pm 1,10 \mathrm{ab}$ & $4,21 \pm 0,73 \mathrm{ab}$ & $4,30 \pm 0,63 \mathrm{a}$ \\
P4 (70\%:30\%) & $3,48 \pm 0,90 \mathrm{c}$ & $3,82 \pm 0,93 \mathrm{ab}$ & $3,39 \pm 1,27 \mathrm{bc}$ & $3,70 \pm 1,06 \mathrm{ab}$ & $3,70 \pm 0,82 \mathrm{~b}$ \\
P5 (60\%:40\%) & $3,09 \pm 1,12 \mathrm{c}$ & $3,30 \pm 1,14 \mathrm{bc}$ & $3,00 \pm 1,24 \mathrm{c}$ & $3,57 \pm 1,34 \mathrm{~b}$ & $3,39 \pm 1,07 \mathrm{~b}$ \\
P6 (50\%:50\%) & $2,39 \pm 0,98 \mathrm{~d}$ & $2,82 \pm 1,27 \mathrm{c}$ & $2,87 \pm 1,32 \mathrm{c}$ & $2,73 \pm 1,35 \mathrm{c}$ & $2,73 \pm 1,05 \mathrm{c}$ \\
\hline
\end{tabular}

Keterangan: Nilai rata-rata yang diikuti oleh huruf yang berbeda pada kolom sama menunjukkan berbeda nyata $(\mathrm{P}<0,05)$

Kriteria hedonik: 1 (tidak suka); 2 (agak tidak suka); 3 (biasa); 4 (agak suka); 5 (suka)

Tabel 5. Nilai rata-rata uji skoring warna, tekstur dan kenampakan pori-pori

\begin{tabular}{cccc}
\hline $\begin{array}{c}\text { Perlakuan } \\
\text { (Terigu : Tepung Millet) }\end{array}$ & Warna & Tekstur (keempukkan) & Kenampakan Pori \\
\hline P1 (100\%:0\%) & $3,96 \pm 0,20 \mathrm{a}$ & $3,78 \pm 0,51 \mathrm{a}$ & $3,43 \pm 0,79 \mathrm{a}$ \\
P2 (90\%:10\%) & $3,26 \pm 0,54 \mathrm{~b}$ & $2,96 \pm 0,56 \mathrm{~b}$ & $3,21 \pm 0,90 \mathrm{a}$ \\
P3 (80\%:20\%) & $2,78 \pm 0,60 \mathrm{c}$ & $2,52 \pm 0,73 \mathrm{c}$ & $3,09 \pm 0,60 \mathrm{~b}$ \\
P4 (70\%:30\%) & $2,04 \pm 0,56 \mathrm{~d}$ & $2,17 \pm 0,71 \mathrm{~cd}$ & $2,73 \pm \mathrm{b} 0,69 \mathrm{c}$ \\
P5 (60\%:40\%) & $1,71 \pm 0,61 \mathrm{de}$ & $1,82 \pm 0,85 \mathrm{~d}$ & $2,60 \pm 0,72 \mathrm{~cd}$ \\
P6 (50\%:50\%) & $1,43 \pm 0,29 \mathrm{e}$ & $1,78 \pm 0,83 \mathrm{~d}$ & $2,21 \pm 0,85 \mathrm{~d}$ \\
\hline
\end{tabular}

Keterangan: Nilai rata - rata yang diikuti oleh huruf yang berbeda pada kolom yang sama menunjukkan berbeda nyata $(\mathrm{P}<0,05)$.

Kriteria skoring warna: 1 (coklat); 2 (coklat keemasan); 3 (kuning keemasan); 4 (kuning muda) Kriteria skoring tekstur: 1 (tidak empuk); 2 (agak empuk); 3 (empuk); 4 (sangat empuk) Kriteria skoring kenampakan pori: 1 (sangat kecil); 2 (kecil); 3 (agak besar); 4 (besar)

\section{Warna}

Hasil sidik ragam menunjukkan bahwa perbandingan terigu dan tepung millet berpengaruh nyata $(\mathrm{P}<0,05)$ terhadap warna donat dengan uji hedonik. Tabel 4 menunjukkan nilai rata- rata uji hedonik donat berkisar antara 2,39 (agak tidak suka) sampai dengan 4,78 (suka). Nilai rata- rata kesukaan panelis terhadap warna tertinggi pada perlakuan P1 dengan kriteria suka dan tidak berbeda nyata dengan perlakuan P2 sedangkan nilai terendah diperoleh perlakuan P6 yaitu dengan kriteria biasa dan tidak berbeda nyata dengan perlakuan P5. 
Tabel 5 menunjukan nilai rata-rata uji skoring donat berkisar antara 1,43 (coklat) sampai dengan 3,96 (kuning muda). Nilai rata-rata skor tertinggi terhadap warna donat diperoleh perlakuan P1 dengan kriteria kuning muda, sedangkan nilai rata-rata skor terendah terdapat pada perlakuan P6 dengan kriteria coklat. Hasil penilaian skoring terhadap warna donat sejalan dengan penilaian warna donat secara fisik. Penilaian fisik donat menghasilkan warna donat yang semakin gelap seiring dengan semakin tinggi penggunaan tepung millet. Hal ini disebabkan karena tepung millet mempunyai warna yang lebih kusam daripada terigu. Warna gelap dari tepung millet diduga akibat adanya tanin dalam tepung tersebut. Katresna (2017) menyatakan bahwa adanya senyawa tanin yang terdapat pada tepung mengakibatkan warna bahan olahan menjadi lebih gelap.

\section{Aroma}

Hasil sidik ragam menunjukkan bahwa perbandingan terigu dan tepung millet berpengaruh nyata $(\mathrm{P}<0,05)$ terhadap aroma donat dengan uji hedonik. Tabel 4 menunjukkan nilai rata- rata uji hedonik donat berkisar antara 2,82 (biasa) sampai dengan 4,21 (agak suka). Nilai rata- rata kesukaan panelis terhadap aroma tertinggi pada perlakuan P1 dengan kriteria suka dan tidak berbeda nyata dengan perlakuan P2 sedangkan nilai terendah diperoleh perlakuan P6 dengan kriteria biasa dan tidak berbeda nyata dengan perlakuan P5. Aroma juga menjadi faktor penentu daya terima panelis karena suatu produk meskipun memiliki warna atau ciri visual yang baik namun aromanya tidak menarik akan mempengaruhi ketertarikan panelis (Khasanah, 2003).

\section{Tekstur}

Hasil sidik ragam menunjukkan bahwa perbandingan terigu dan tepung millet berpengaruh nyata $(\mathrm{P}<0,05)$ terhadap nilai sensoris kesukaan tekstur donat. Tabel 4 menunjukkan nilai rata-rata uji hedonic berkisar antara 2,87 (biasa) sampai dengan 4,04 (agak suka). Nilai rata-rata kesukaan panelis terhadap tekstur tertinggi pada perlakuan P1 dengan kriteria suka dan tidak berbeda nyata dengan perlakuan P2 sedangkan nilai terendah diperoleh perlakuan P6 dengan kriteria biasa dan tidak berbeda nyata dengan perlakuan P5 dan P4. Tabel 5 menunjukan nilai rata-rata uji skoring donat berkisar antara 1,78 (agak empuk) sampai dengan 3,78 (sangat empuk). Nilai rata-rata skor tertinggi terhadap tekstur donat diperoleh pada perlakuan P1 dengan kriteria sangat empuk, nilai rata-rata skor terendah terdapat pada perlakuan P6 dengan kriteria agak empuk dan tidak berbeda nyata dengan perlakuan P4 dan P5. Semakin tinggi penggunaan tepung millet maka nilai keempukan donat semakin menurun. Hal ini disebabkan karena peningkatan penggunaan tepung millet akan mengurangi jumlah gluten pada adonan tepung. Gluten pada adonan tepung berfungsi untuk menahan gas 
yang terbentuk sehingga donat dapat mengembang dengan struktur beronggarongga halus dan seragam serta tekstur empuk dan elastis (Wahyudi, 2003 dalam Waruwu et al., 2015).

\section{Kenampakan Pori-Pori}

Hasil sidik ragam menunjukkan bahwa perbandingan terigu dan tepung millet berpengaruh nyata $(\mathrm{P}<0,05)$ terhadap nilai skoring kenampakan pori-pori donat. Tabel 5 menunjukan nilai rata-rata uji skoring donat berkisar antara 2,21 (kecil) sampai dengan 3,43 (agak besar). Nilai rata-rata skor tertinggi terhadap kenampakan poripori donat diperoleh pada perlakuan P1 dengan kriteria besar, nilai rata-rata skor terendah terdapat pada perlakuan P6 dengan kriteria kecil dan tidak berbeda nyata dengan P5. Semakin tinggi penggunaan tepung millet maka pori-pori donat semakin kecil hal ini dikarenakan kandungan gluten dari donat akan semakin rendah. Hasil penilaian skoring terhadap kenampakan pori donat sejalan dengan penilaian daya kembang donat secara fisik. Penilaian fisik donat menghasilkan daya kembang yang semakin menurun dan pori-pori yang semakin mengecil seiring dengan semakin tinggi penggunaan tepung millet. Penurunan kemampuan adonan menahan gas yang terutama dipengaruhi kandungan gluten sehingga pengembangan yang makin tidak baik, akibatnya pori-pori tidak merata (Surono et al., 2017). Vinning dan
Mcmahon (2006) menyatakan bahwa millet merupakan salah satu serealia yang tidak mengandung gluten selain jagung, beras, amaranth, quinoa dan sorghum.

\section{Rasa}

Hasil sidik ragam menunjukkan bahwa perbandingan terigu dan tepung millet berpengaruh nyata $(\mathrm{P}<0,05)$ terhadap rasa donat dengan uji hedonik. Tabel 4 menunjukkan nilai rata- rata uji hedonik donat berkisar antara 2,73 (biasa) sampai dengan 4,30 (agak suka). Nilai rata-rata kesukaan panelis terhadap rasa tertinggi pada perlakuan P1 dengan kriteria suka dan tidak berbeda nyata dengan perlakuan P2, P3 dan P4 sedangkan nilai terendah diperoleh perlakuan P6 yaitu dengan kriteria biasa. Donat dengan perlakuan P1 sampai dengan P4 berada dalam kategori tingkat kesukaan yang sama, yaitu agak suka, sehingga dapa dikatakan bahwa panelis dapat menerima donat dengan penggunaan tepung millet sampai dengan $30 \%$. Penggunaan tepung millet diatas $30 \%$ memberikan rasa yang agak pahit. Rasa pahit dari millet diakibatkan karena kandungan tanin pada millet (Pratiwi dan Hapsari., 2019).

\section{Penerimaan Keseluruhan}

Hasil sidik ragam menunjukkan bahwa perbandingan terigu dan tepung millet berpengaruh nyata $(\mathrm{P}<0,05) \quad$ terhadap penerimaan keseluruhan donat dengan uji 
hedonik. Tabel 4 menunjukkan nilai ratarata uji hedonik donat berkisar antara 2,73 (biasa) sampai dengan 4,48 (agak suka). Nilai rata-rata kesukaan panelis terhadap penerimaan keseluruhan tertinggi pada perlakuan P1 dengan kriteria agak suka dan tidak berbeda nyata dengan perlakuan P2 dan P3, sedangkan nilai terendah diperoleh perlakuan P6 yaitu dengan kriteria biasa. Penerimaan keseluruhan dipengaruhi oleh beberapa faktor seperti warna, aroma, tekstur, kenampakan pori-pori, dan rasa donat. Berdasarkan hasil penilaian panelis terhadap nilai sensoris penerimaan keseluruhan pada donat, donat yang memiliki kriteria agak suka yaitu pada perlakuan P1, P2, P3, dan P4.

\section{KESIMPULAN DAN SARAN Kesimpulan}

Perbandingan terigu dan tepung millet berpengaruh terhadap daya kembang, kuantitas warna, kadar air, kadar protein, kadar tannin, kadar serat kasar, warna, aroma, tekstur, kenampakan pori-pori, rasa dan penerimaan keseluruhan.

Perbandingan terigu $80 \%$ dan tepung millet $20 \%$ menghasilkan donat dengan karakteristik terbaik dengan daya kembang $116,69 \%$, kuantitas warna dengan nilai $\mathrm{L}$ 52,77, a* 9,51, b*34,37, kadar air 25,88\%, kadar protein $8,17 \%$, kadar serat kasar $5,06 \%$, kadar tanin $0,15 \%$, warna kuning keemasan dan agak suka, aroma agak suka, tekstur agak empuk dan agak suka, kenampakan pori-pori agak besar, rasa agak suka, dan penerimaan keseluruhan agak suka

\section{Saran}

Disarankan menggunakan perbandingan terigu $80 \%$ dan tepung millet $20 \%$ dalam pembuatan donat millet, serta perlu dilakukan penelitian lebih lanjut mengenai masa simpan donat millet.

\section{DAFTAR PUSTAKA}

Abdel-Rahaman, S.M., E.E. Babiker, dan A.H. El-Tinay. 2005. Effect of fermentation on antinutritional factors and $\mathrm{HCl}$ extraction of minerals of pearl millet cultivars. J. Food Technology 3(4), 516-522.

Ahza AB. 1983. Subtitusi Parsial Tepung Gandunm (Triticum aestivum L.) dengan Tepung Sorghum (Sorghum bicolor (L.) Moench) dan Tepung Kacang Tunggak (Vigna ungui culata (L.) Walp) pada pembuatan Roti.Tesis. Fakultas Pascasarjana IPB, Bogor.

Anggarini, E.F dan K Dwi. 2015. Pengaruh Substitusi Bekatul (Rice Bran) Terhadap Sifat Organoleptik Donat. EJournal Boga, 4(8):63-70

Anonimus. 2009. Standar Nasional Indonesia (SNI) 3751:2009. Terigu Sebagai Bahan Makanan. Badan Standarisasi Nasional. Jakarta

Bakrie, A. 1990. Mempelajari Pengaruh Penggunaan Tepung Campuran Terigu dan Tapioka terhadap Mutu Roti Manis. Jember: Pusat Penelitian Univ. Jember.

Belinda, A. S., dan Yunianta. 2016. Uji sifat fisio kimia dan organoleptik minuman sari biji kecipir dengan penambahan enzim papain. $J$ Pangan dan Agroindustri, 4(1), 148-157.

Dewi, IG. A. A. S. Padma., IG. A. Ekawati dan I. D.P.K. Pratiwi. 2018. Pengaruh 
Lama Perkecambahan Millet (Panicum milliaceum) Terhadap Karakteristik Flakes. Jurnal ITEPA. 7(4): 175-183.

Faridah, A., dan B. Widjanarko., 2014. Penambahan Tepung Porang Pada Pembuatan Mi Dengan Subtitusi Tepung Mocaf (Modified Cassava Flour). Jurnal Teknologi Dan Industri Pangan, 25(1): 98-105.

Hartika, W. 2009. Kajian Sifat Fisik dan Kimia Tepung Biji Nangka (Artocarpusheterophyllus lamk) dan Aplikasinya Dalam Pembuatan Roti Manis. Skripsi. Tidak Dipublikasikan. Fakultas Teknologi Pertanian. Universitas Andalas. Padang.

Hartono, S. D. 2010. Optimasi Pembuatan Tepung Millet (Setaria $s p$.) Termodifikasi dan Aplikasinya Sebagai Bahan Dasar Roti Tawar (Tinjauan dari Kadar Protein Terlarut, Kadar Gizi, dan Asam Amino). Skripsi. Tidak dipublikasikan. Universitas Kristen Satya Wacana.

Katresna, N.P .2017. Pengaruh Substitusi Tepung Modifikasi Sorgum (Shorgum Bicolor L.) Dan Terigu Dengan Penambahan Bekatul Beras (Oryzae Sativa L.) Terhadap Karakteristik Cookies. Skripsi. Fakultas Teknik. Universitas Pasundan, Bandung.

Khasanah, U. 2003. Formulasi karakterisasi fisiko-kimia dan organoleptic produk makanan sarapan ubi jalar (sweet potato flakes). Skripsi. Tidak dipublikasikan. Institute Pertanian Bogor, Bogor

Kindiki, M.M., A. Onyago dan F. Kyalo. 2015. Effect of Processing on Nutritional and Sensory Quality of Pearl Millet Flour. Food Science and Quality Management 42: 13-19.

Listiyarini,T.2016. Naik ke Peringkat 2 Dunia Impor Gandum RI Capai 8,1 Juta Ton. http://www.beritasatu.com/ekonomi/3 $\underline{\text { 37466-naik-ke-peringkat-dua- }}$
duniaError! Hyperlink reference not valid.

Mahendra, P. E. Ditya, N. L. A. Yusasrini dan I. D. P. K. Pratiwi. 2019. Pengaruh Metode Pengolahan Terhadap Kandungan Tanin Dan Sifat Fungsional Tepung Proso Millet (Panicum miliaceum). Jurnal ITEPA. 8(4): 354-367.

Matz, S.A. (1992). Bakery Technology and Engineering, 3th Edition. Van Nostrand Reinhold. Texas.

National Nutrient Database, 2012. Full Report (All Nutrients): 20031, Millet, raw.

https://ndb.nal.usda.gov/ndb/foods/sh ow/20031 diakses pada tanggal 14 April 2020.

Nugrahani, D. M. 2005. Perubahan Karakteristik dan Kualitas Protein Pada Mie Basah Matang yang Mengandung Formaldehid dan Boraks. Skripsi. Fakultas Teknologi Pertanian, IPB. Bogor

Potter, N. N. 1978. Food Science. Third Ed.The Avi Publishing Co. Inc. Wessport,Connecticut.

Pratiwi, I. D. P. K. dan N. M. I. Hapsari. 2019. Nilai Protein, B-Karoten Dan Sensoris Biskuit Bayi Dari Tepung Ubi Jalar Kuning Dan Tepung Millet Terfermentasi. Media Ilmiah Teknologi Pangan, 6(1): 66-75.

Pratiwi, I.D.P.K dan I.M.Sughita. 2020. Kandungan Tanin dan Serat Pangan dari Tepung Kecambah Millet dan Tepung Kecambah Millet Terfermentasi. Jurnal Ilmiah Teknologi Pertanian, 5(1):34-38.

Raharjo, M.P. 2019. Formulasi Roti Tawar Menggunakan Tepung Komposit berbasis Tepung Sorgum Sebagai Olahan Pangan Bebas gluten Bagi Penyandang Autis. Skripsi. Tidak Dipublikasikan. Universitas Katolik Soegijapranata.

Sarofa, U., S. Djajati., dan S.N. Cholifah. 2014. Pembuatan Roti manis (kajian 
subtitusi tepung terigu dan kulit manggis dengan penambahan gluten). Jurnal rekapangan, 8(2): 171-178.

Soekarto, S.T. 1985. Penilaian Organoleptik (untuk Industri Pangan dan Hasil Pertanian). Penerbit Bharata Karya Aksara, Jakarta.

Subagjo, A. 2007. Manajemen Pengolahan Kue dan Roti. Graha Ilmu. Yogyakarta. Sunarsi, S., M. Sugeng., S. Wahyuni, dan W. Ratnaningsih. 2011. Memanfaatkan singkong menjadi tepung mocaf untuk pemberdayaan masyarakat Sumberejo. Pangan dan Agroindustri, 1(1): 306-316.

Sudarmadji, S., B. Haryono, dan Suhardi. 1997. Prosedur Analisis Untuk Bahan Makanan dan Pertanian. Liberty. Yogyakarta.

Surono, D.I., E.J.N. Nurali; J.S.C. Moningka MS. (2017). Kualitas Fisik dan Sensoris Roti Tawar Bebas Gluten Bebas Kasein Berbahan Dasar Tepung Komposit Pisang Goroho (Musa acuminate L). Jurnal Teknologi Pertanian 1 (1): 1-12.

Swandani, N. P. Putri, P. A. S. Widpradnyadewi dan P. T. Ina. 2017. Pengaruh Perbandingan Terigu Dan Buah Lindur (Bruguiera Gymnorrhiza L.) Terhadap Karakteristik Donat. Jurnal ITEPA. 6(1): 40-49.

Syahputri, D. A. dan A. K. Wardani. 2014. Pengaruh Fermentasi Jali (Coix Lacryma Jobi- L) Pada Proses Pembuatan Tepung Terhadap Karakteristik Fisik Dan dan Kimia Cookies dan Roti Tawar. Jurnal Pangan dan Agroindustri, 3(3) 984985.

Tamba, M., S. Ginting, dan L.N. Limbong, 2014. Pengaruh Substitusi Tepung Labu Kuning Pada Tepung Terigu Dan. Jurnal Rekayasa Pangan Dan Pertanian, 2(2):123.

Vinning, G dan G. McMahon. 2006. Gluten-free grains: a demand-andsupply analysis of prospects for the
Australian health grains industry. A report for the Rural Industries Research and Development Corporation, Australia.

Waruwu, F., E. Julianti, dan S. Ginting. 2015. Evaluasi karakteristik fisik, kimia dan sensoris roti tepung komposit beras, ubi kayu, kentang dan kedelai dengan penambahan xanthan gum. Jurnal Rekayasa Pangan Dan Pertanian. 3(4): 448-457.

Wijayanti. 2007. Substitusi Tepung Gandum (Triticum aestivum) dengan Tepung Garut (Maranta arundinaceae $L)$ pada Pembuatan Roti Tawar. Skripsi. Fakultas Teknologi Pertanian, Universitas Gadjah Mada, Yogyakarta.

Winarno, F.G. 1992. Kimia Pangan dan Gizi. PT. Gramedia Pustaka Utama. Jakarta.

Wrigley, C. W., F. Békés, dan W. Bushuk. 2006. Gluten: A balance of gliadin and glutenin, in Gliadin and glutenin. The unique balance of wheat quality, C. W. Wrigley, F. Békés, and W. Bushuk, Eds., St. Paul, MN, USA: AACC Inc. (1-32). 